\title{
Bilgisayarlı Tomografi İle Üriner Sistem Taşlarının Yapısı Tahmin Edilebilir Mi?
}

\author{
Merve Gülbiz Dagoglu Kartal ${ }^{1}$, Erhan Çelenk ${ }^{1}$, Yılmaz Önal ${ }^{1}$, Barış Bakır ${ }^{1}$
}

${ }^{1}$ İstanbul Üniversitesi, İstanbul Tıp Fakültesi, Radyoloji Anabilim Dalı, İstanbul

Giriş

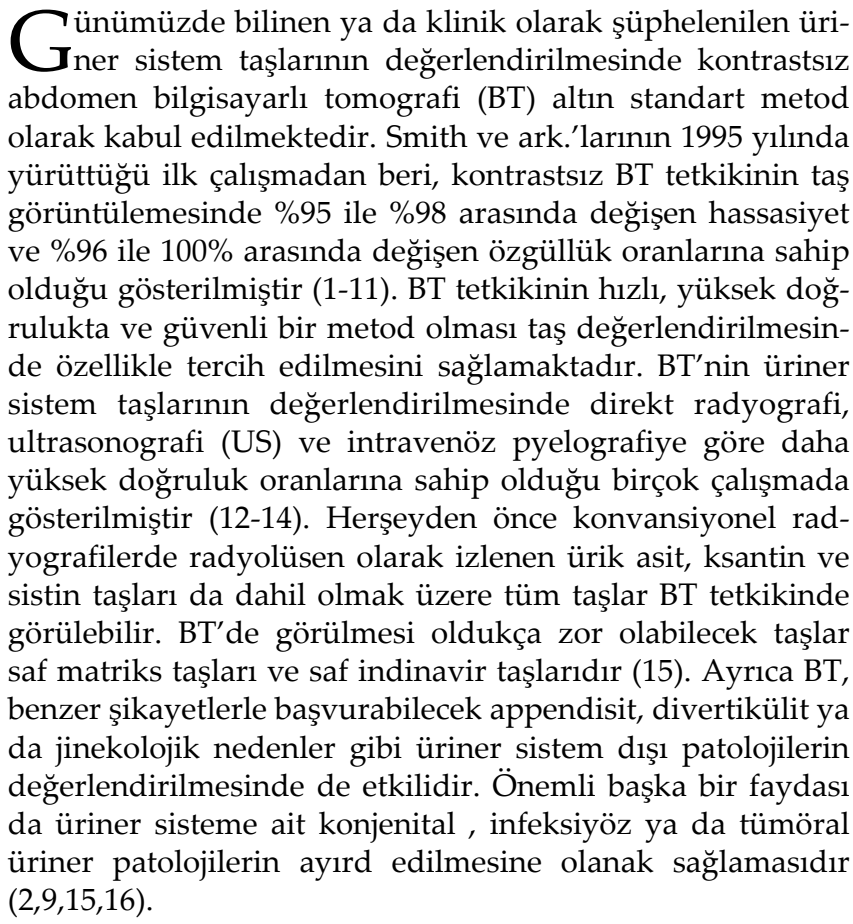

\section{BT ile taşların iç yapısının değerlendirilmesi}

BT'nin taş varlığını ve lokalizasyonun saptamada elde edilen yüksek doğruluk oranları, taşların içyapısının değerlendirilmesinde oldukça kısıtlıdır (17). Oysa ki taşların içyapısının tedavi seçeneklerinin değerlendirilmesi ve tedaviye cevabın öngörülmesinde önemli bir etken olduğu bilinmektedir. Aynı zamanda taş yapısının bilinmesi altta yatan metabolik süreci aydınlatacağından taş oluşumunun tekrarlamaması için gerekli profilaktik tedavinin verilmesini sağlayacaktır. Bu konuda yapılan ilk çalışmalarda farklı yapılardaki taşların büyüklükleri ve Hounsfield ünitesi (HU) ile ölçülen ve attenüasyon değerlerini gösteren taş dansiteleri değerlendirilmiştir $(18,19)$.

Bellin ve ark.'ları in vitro yürüttükleri bir çalışmada BT attenüasyon değerlerini kullanarak taş yapısının \%64-81 doğruluk oranıla belirlenebileceğini göstermişlerdir (20). Ürik asit, sistin, kalsiyum oksalat monohidrat ve brusit taşları in vitro olarak \%85'in üzerinde doğruluk oranıyla gösterilebilmiştir (20-23). Ancak in vivo şartlarda taş yapısını ayırmak daha zor ve daha az güvenilirdir. Herşeyden önce ölçümün doğruluğu taşın boyutuna ve ölçüm yapılan yerin uygunluğuna göre değişiklik gösterir. Ayrıca karma yapılı taşlarda ölçüm daha karmaşık hale gelmektedir (24). Farklı yapılardaki taşların attenüasyon değerleri birbirine yakın olduğu için bu teknikle yalnızca dansiteleri çok yüksek olan oksalat kristalleri ile dansiteleri çok düşük olan ürik asit kristalleri tanımlanabilmiştir. Kalsiyum fostat, sistin, magnezyum amonyum fosfat ve karma kalsiyum oksalat ve fosfat taşları birbirlerinden ayırd edilememektedir (18-27).

BT tetkikinde kesit kalınlığı ve taş boyutu da attenüasyon değerlerini etkileyen faktörler olarak gösterilmiştir. Bu çalışmalardan elde edilen verilere göre dansite değerleri taş boyutunun kesit kalınlığına oranı arttıkça en yüksek seviyeye ulaşmaktadır. Bu durumda kesit kalınlığı arttırıldığında taşlara ait dansite değerlerinin arttığı ve $5 \mathrm{~mm}$ 'den küçük taşların kendileriyle aynı yapıda olsalar da daha büyük taşlara göre daha düşük dansite değerlerine sahip olduğu gösterilmiştir $(18,27)$.

Yapılan bazı çalışmalarda BT ile iki farklı enerji seviyesinde X-1şını tarama yapılarak elde edilen dansite değerlerinin birbirine oranı hesaplanmıştır. Bu şekilde yüksek enerjili (120 veya $140 \mathrm{kV}$ ) $1 s ̧ ı n$ kullanıldğında birbirinden ayrılamayan kalsiyum oksalat ile kalsiyum fostat taşları düşük enerjili $(80 \mathrm{kV})$ ışın ile de tarandığında, iki farklı taş için iki farklı tetkikte elde edilen dansiteler arasında anlamlı fark elde edilmiştir (25). Başka bir çalışmada ürik asit taşları sistin ve sitruvit taşlarından 77 ve $125 \mathrm{kV}$ gibi iki farklı enerji değerinde elde edilen dansite ölçümleriyle ayırd edilebilmiştir (28). Ancak bu çalışmada da kalsiyum oksalat ve fosfat taşları arasında ayrım yapılamamıştır.

Yakın zamanda Ouzaid ve ark.'ları 50 hasta üzerinde yaptıkları bir çalışmada extracorporeal shock wave lithotripsy (ESWL) tedavisine cevabın taşın dansitesiyle öngörülebileceğini ve bunun için belirlenen değerin $970 \mathrm{HU}$ olduğunu göstermişlerdir (29). Bu çalışma kontrastsız BT tetkikinde yapılan dansite ölçümünün tedavi şansının belirlenmesinde yararlı olabileceğini gösterir önceki çalışmaları desteklemektedir (30-32). Kijvikai ve ark.'ları da 2011 yılında yayınlanan derlemelerinde taş dansitesinin tek başına taş yapısının ve ESWL tedavisine cevabın öngörülmesinde yeterli olmayacağını, bu amaçla taş morfolojisine yönelik detaylı incelemelerin üzerinde çalışılması gerektiğini vurgulamıştır (33). 

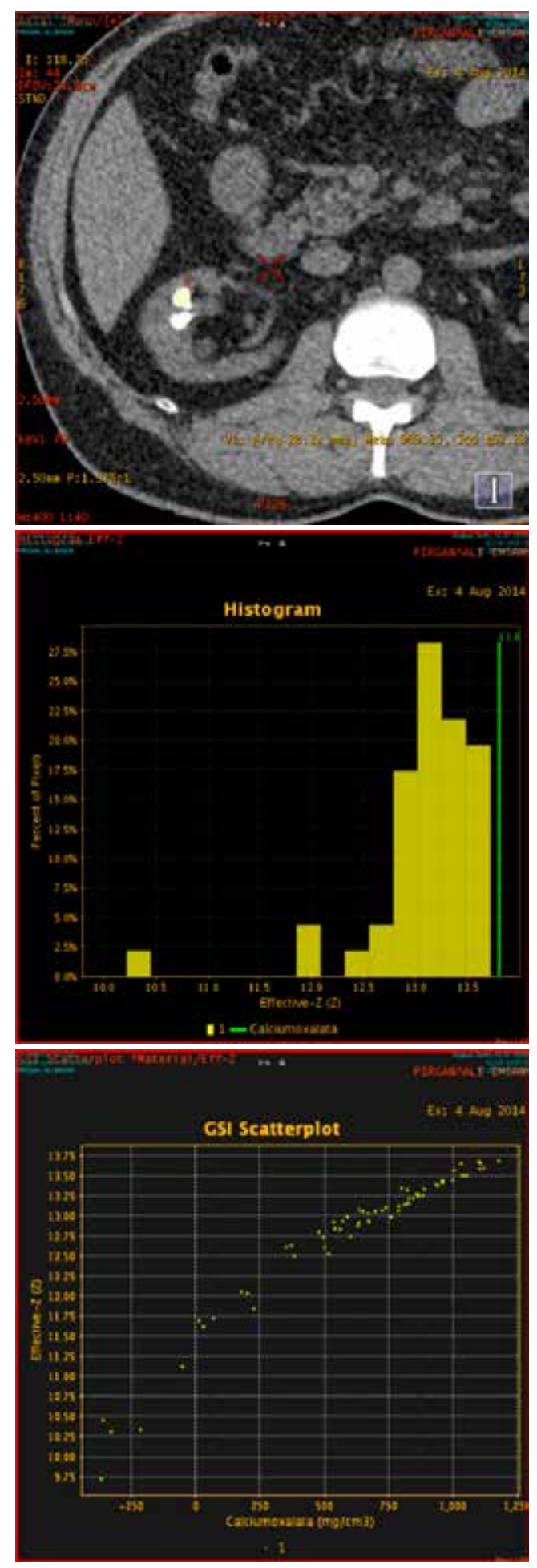

Resim: Sağ böbrek orta kesimde kaliksler içerisinde izlenen taşların 64-dedektör BT'de (Discovery CT 750HD, GE Healthcare, Milwaukee, Wisconsin) hizlı voltaj değiştirme tekniği ile elde olunmuş axial plan BT görüntüsü izlenmektedir. Kullanılan dual enerji protokolü Gemstone spektral görüntüleme (Gemstone Spectral Imaging -GSI) :rotasyon zamanı $0.6 \mathrm{~s}$; pitch 1.375:1; detektör genişliği 20 mmve kesit kalınlığ $1.25 \mathrm{~mm}$ enerji: 80 and $140 \mathrm{kVp}$. Dual enerji görüntüleri işistasyonunda (Advantage Windows, version 4.5; GE Healthcare) değerlendirilmiș ve izlenen taşın üstüne ilgilenilen alanın belirlendiği region of interest (ROI) uygulanmıştır (a). Etkin $\mathrm{Z}$ değeri belirlenen alan içerisindeki etkin anatomik sayıyı belirlemektedir (b). Elde olunan data ile histogram (d) ve spektral eğri analizi (e)yapılıp izlenen taşın kalsiyum oksalat içerdiği gösterilmiştir.

\section{Dual Enerji BT}

Günümüz teknolojisindeki gelişmelerle artan bir hızla klinik kullanıma giren dual enerji BT sistemleri, aynı anatomik lokalizasyondan aynı anda yüksek ve düşük enerjili olmak üzere iki farklı x-ışını spektrumunda, iki farklı görüntü elde edeceğinden, lezyonların iç yapısının incelenmesinde daha detaylı bir bilgi sunmaktadır (34). Kontrastsız BT ile tek fazda tarandığında benzer attenüasyon değerleri nedeniyle birbirinden kolaylıkla ayrılamayacak olan farklı yapılardaki taşlar da; dual BT'de yüksek ve düşük enerjili ışınlar gönderildiğinde oluşan farklı attenüasyon değerleri nedeniyle birbirlerinden ayırd edilebilirler. Benzer şekilde, iki ayrı enerji değeriyle, iki taramayla elde edilen görüntülerle kıyaslandığında bu sistemde elde edilen görüntüler tek fazda aynı noktadan edinilmektedir. Bu nedenle görüntüler birbirleriyle karşılaştırılırken hareket artefaktından etkilenmemektedir.

Dual enerji BT, özellikle ürik asid içeren taşlarla ürik asit içermeyenleri yüksek doğruluk oranlarıyla gösterebilmektedir $(35,36)$. Stolzmann ve ark.'larının yaptığı çalışmada tetkikin ürik asit taşlarını saptamadaki hassasiyeti \%89, özgüllüğü \%98 olarak bildirilmiştir (36). Ürik asit taşları ağırlıklı olarak karbon, oksijen, nitrojen gibi düşük molekül ağırlıklı yapılar içerdiğinden düşük ve yüksek enerji $X$-ışınlarıyla diğer taş tiplerinden daha farklı şekilde etkileşim gösterirler. Çünkü kalsiyum oksalat, hidroksiapatit ve sistin taşları fosfor, kalsiyum ya da sülfür gibi yüksek molekül ağırlıklı elementler içerir ve bu nedenle düşük enerjide bile yüksek HU değerlerine sahiptir (37). Yakın zamanda yapılan çalışmalar dual BT ile sistin ve sitruvit içeren taşların kalsiyum içeren taşlardan ayırd edilebildiğini göstermektedir (38-40) (Resim).

Dual enerji BT'nin taşların içyapısının değerlendirilmesinde güvenilir bir yöntem olduğu in vivo ve in vitro çalışmalarda gösterilmiştir (41-43). Ancak BT'de olduğu gibi taş büyüklüğü de özellikle $1 \mathrm{~cm}$ 'in altındaki taşların değerlendirilmesinde dual enerji BT'de elde edilen sonuçları etkilemektedir. Aynı zamanda dual enerji BT, daha fazla radyasyon dozu içermektedir (41). Dolayısıyla, dual enerji BT taşların içyapısının belirlenmesinde önemli bir adım gibi görünmekle beraber tetkikin yan etkileri de olabileceği düşünülerek zayıflıklarının ve üstünlüklerinin doğru belirlenebilmesi için daha geniş serilerde daha çok çalışmaya ihtiyaç vardır.

\section{Kaynaklar}

1. Smith RC, Rosenfield AT, Choe KA, et al. Acute flank pain: comparison of non-contrast-enhanced CT and intravenous urography. Radiology 1995; 194:789-794.

2. Smith RC, Verga M, McCarthy S, Rosenfield AT. Diagnosis of acute flank pain: value of unenhanced helical CT. AJR Am J Roentgenol 1996; 166: 97-101.

3. Fielding JR, Steele G, Fox LA, Heller H, Loughlin KR. Spiral computerized tomography in the evaluation of acute flank pain: a replacement for excretory urography. J Urol 1997;157: 2071-2073.

4. Fielding JR, Fox LA, Heller H, et al. Spiral CT in the evaluation of flank pain: overall accuracy and feature analysis. J Comput Assist Tomogr 1997; 21: 635-638.

5. Fielding JR, Silverman SG, Samuel S, Zou KH, Loughlin $\mathrm{KR}$. Unenhanced helical CT of ureteral stones: a replacement for excretory urography in planning treatment. AJR Am J Roentgenol 1998; 171:1051-1053. 
6. Boulay I, Holtz P, Foley WD, White B, Begun FP. Ureteral calculi: diagnostic efficacy of helical CT and implications for treatment of patients. AJR 1999;172:1485-1490.

7. Katz DS, Lane MJ, Sommer FG. Unenhanced helical CT of ureteral stones: incidence of associated urinary tract findings. AJR Am J Roentgenol 1996; 166:1319-1322.

8. Hamm M, Wawroschek F, Weckermann D, et al. Unenhanced helical computed tomography in the evaluation of acute flank pain. Eur Urol 2001; 39: 460-465.

9. Dalrymple NC, Verga M, Anderson KR, et al. The value of unenhanced helical computerized tomography in the management of acute flank pain. J Urol 1998;159:735-74.

10. Sheley RC, Semonsen KG, Quinn SF. Helical CT in the evaluation of renal colic. Am J Emerg Med 1999; 17:279282.

11. Miller OF, Rineer SK, Reicherd SR, et al. Prospective comparison of unenhanced spiral computed tomography and intravenous urography in the evaluation of acute flank pain. Urology 1998; 52:982-987.

12. Smith RC. Ureteral calculi in patients with flank pain: correlation of plain radiography with unenhanced helical CT. Radiology 1997; 204: 27-31.

13. Sommer FG, Jeffrey RBJ, Rubin GD, et al. Detection of ureteral calculi in patients with suspected renal colic: value of reformatted noncontrast helical CT. AJR 1995;165:509-513.

14. Yilmaz S, Sindel T, Arslan G, et al. Renal colic: comparison of spiral CT, US and IVU in the detection of ureteral calculi. Eur Radiol 1998; 8:212-217.

15. Smith RC, Coll DM. Helical computed tomography in the diagnosis of ureteric colic. BJU Int 2000;86(suppl 1):33-41.

16. Chen MY, Zagoria RJ, Saunders HS, Dyer RB. Trends in the use of unenhanced helical CT for acute urinary colic. AJR Am J Roentgenol 1999; 173:1447-1450.

17. Kaza RK, Platt JF, Cohan RH, Caoili EM, Al-Hawary MM, Wasnik A. Dual-energy CT with single- and dulasource scanners: Current Applications in evaluating the genitourinary tract. RadioGraphics 2012;32:353-369.

18. Kuwahara M, Kageyama S, Kurosu S, Orikasa S. Computed tomography and composition of renal calculi. Urol Res 1984;12(2):11-3.

19. Nakada SY, Hoff DG, Attai S, Heisey D, Blankenbaker D, Pozniak M. Determination of stone composition by non- contrast spiral computed tomography in the clinical setting. Urology 2000 ;55: 816-9.

20. Bellin MF, Renard-Penna R, Conort P, et al. Hel-ical CT evaluation of the chemical composition of urinary tract calculi with a discriminant analysis of CT-attenuation values and density. Eur Radiol 2004;14: 2134-2140.

21. Dretler SP. Calculus breakability: fragility and durility. J Endourol 1994;8(1):1-3.

22. Rassweiler JJ, Renner C, Chaussy C, Thüroff S. Treatment of renal stones by extracorporeal shockwave lithotripsy: an update. Eur Urol 2001; 39: 187-199.

23. Renner C, Rassweiler J. Treatment of renal stones by extracorporeal shock wave lithotripsy. Nephron 1999;81(suppl 1):71-81.

24. da Silva SF, Silva SL, Daher EF, Silva Junior GB, Mota RM, Bruno da Silva CA. Determination of urinary stone composition based on stone morphology: a prospective study of 325 consecutive patients in an emerging country. Clin Chem Lab Med 2009; 47: 561-564.
25. Mostafavi MR, Ernst RD, Saltzman B. Accurate determination of chemical composition of urinary calculi by spiral computerized tomography. J Urol 1998; 159: 673-675.

26. Motley G, Dalrymple N, Keesling C, Fischer J, Harmon W. Hounsfield unit density in the determination of urinary stone composition. Urology 2001; 58:170-173.

27. Parienty RA, Ducellier R, Pradel J, Lubrano J-M, Coquille F, Richard F. Diagnostic value of CT numbers in pelvocalyceal filling defects. Radiology 1982;145:743747.

28. Mitcheson HD, Zamenhof RG, Bankoff MS, Prien EL. Determination of the chemical composition of urinary calculi by computerized tomography.J Urol 1983;130:814819.

29. Ouzaid I, Al-qahtani S, Dominique S, Hupertan V, Fernandez P, Hermieu JF, Delmas V, Ravery V. A 970 Hounsfield units (HU) threshold of kidney stone density on non-contrast computed tomography (NCCT) improves patients' selection for extracorporeal shockwave lithotripsy (ESWL): evidence from a prospective study. BJU Int. 2012; 110(11 Pt B): E438-42.

30. Weld KJ, Montiglio C, Morris MS, et al. Shock wave lithotripsy success for renal stones based on patient and stone computed tomography characteristics. Urology 2007; 70:1043-1046.

31. Wiesenthal JD, Ghiculete D, D'A Honey RJ, Pace KT. Evaluating the importance of mean stone density and skin-to-stone distance in predicting successful shock wave lithotripsy of renal and ureteric calculi. Urol Res 2010;38:307-313.

32. Gupta NP, Ansari MS, Kesarvani P, Kapoor A, Mukhopadhyay S. Role of computed tomography with no contrast medium enhancement in predicting the outcome of extracorporeal shock wave lithotripsy for urinary calculi. BJU Int. 2005; 95: 1285-8.

33. Kijvikai K, de la Rosette JJ. Assessment of stone composition in the management of urinary stones. Nat Rev Urol. 2011; 8:81-5.

34. Eliahou R, Hidas G, Duvdevani M, Sosna J. Determination of renal stone composition with dual-energy computed tomography: an emerging application. Semin Ultrasound CT MR 2010; 3: 315-320.

35. Primak AN, Fletcher JG, Vrtiska TJ, et al. Noninvasive differentiation of uric acid versus non-uric acid kidney stones using dual-energy CT. Acad Radiol 2007; 14:14411447.

36. Stolzmann $\mathrm{P}$, Kozomara $\mathrm{M}$, Chuck $\mathrm{N}$, et al. In vivo identification of uric acid stones with dual-energy CT: diagnostic performance evaluation in patients. Abdom Imaging 2010; 35: 629-635.

37. Mc Laughlin PD, Crush L, Maher MM, O'Connor OJ. Recent developments in computed tomography for urolithiasis: diagnosis and characterization. Adv Urol. 2012; 2012: 606754 .

38. Vrtiska TJ, Takahashi N, Fletcher JG, Hartman RP, Yu L, Kawashima A. Genitourinary applications of dual-energy CT. AJR Am J Roentgenol 2010; 194: 1434-1442.

39. Hidas G, Eliahou R, Duvdevani M, et al. Determination of renal stone composition with dual-energy CT: in vivo analysis and comparison with x-ray diffraction. Radiology 2010; 257: 394-401. 
40. Joshi M, Langan DA, Sahani DS, et al. Effective atomic number accuracy for kidney stone characterization using spectral CT. In: Samei E, Pelc NJ, eds. Proceedings of SPIE: medical imaging 2010. Vol 7622. Bellingham, Wash: International Society for Optical Engineering, 2010.

41. Manglaviti G, Tresoldi S, Guerrer CS, Di Leo G, Montanari E, Sardanelli F, Cornalba G. In vivo evaluation of the chemical composition of urinary stones using dual-energy CT. AJR Am J Roentgenol. 2011;197: W76-83.

42. Thomas C, Patschan O, Ketelsen D, Tsiflikas I, Reimann A, Brodoefel H, Buchgeister M, Nagele U, Stenzl A, Claussen C, Kopp A, Heuschmid M, Schlemmer HP. Dual-energy $\mathrm{CT}$ for the characterization of urinary calculi: In vitro and in vivo evaluation of a low-dose scanning protocol. Eur Radiol. 2009;19:1553-9.
43. Thomas C, Heuschmid M, Schilling D, Ketelsen D, Tsiflikas I, Stenzl A, Claussen CD, Schlemmer HP. Urinary calculi composed of uric acid, cystine, and mineral salts: differentiation with dual-energy CT at a radiation dose comparable to that of intravenous pyelography. Radiology. 2010; 257: 402-9.

44. Graser A, Johnson TR, Bader M, Staehler M, Haseke N, Nikolaou K, Reiser MF, Stief CG, Becker CR. Dual energy CT characterization of urinary calculi: initial in vitro and clinical experience. Invest Radiol. 2008; 43: 112-9.

Yazışma Adresi:

Merve Gülbiz Dagoglu Kartal,

İstanbul Üniversitesi, İstanbul Tıp Fakültesi, Radyoloji Anabilim Dal, İstanbul

Tel: +90 5326527552

e-mail: gulbizkartal@gmail.com 